\title{
Conservative treatment with brace and exercise for hyperkyphosis: a retrospective observational cohort study
}

\author{
Salvatore Minnella ${ }^{1 *}$, Sabrina Donzelli ${ }^{1}$, Monia Lusini ${ }^{1}$, Fabio Zaina ${ }^{1}$, Michele Romano ${ }^{1}$, Alessandra Negrini ${ }^{1}$, \\ Stefano Negrini \\ From 11th International Conference on Conservative Management of Spinal Deformities - SOSORT 2014 \\ Annual Meeting \\ Wiesbaden, Germany. 8-10 May 2014
}

\section{Background}

There are different types of hyperkyphosis which require specific strategies of treatment but there is little evidence in regard to its conservative treatment.

\section{Aim of the study}

This study aim to assess conservative treatment of idiopathic and Scheuermann's kyphosis by brace and specific exercise

\section{Design}

This is a retrospective observational study on consecutive outpatients from a prospective database started in March 2003

\section{Methods}

\section{Setting}

Outpatient tertiary referral clinic specialized in conservative treatment of spinal deformities.

\section{Participants}

In December 2013, among all the patients below 18 years of age at first evaluation, present in the database, we selected those respecting the following inclusion criteria:

- diagnosis of idiopathic or Scheuermann's kyphosis

- at least two clinical evaluations at the time of therapy start (T0) and stop (T1)

- spinal X-rays (lateral projection) at the time T0 and T1

${ }^{1}$ ISICO, Italian Scientific Spine Institute, Milan, Italy

Full list of author information is available at the end of the article

\section{Treatments}

All patients underwent conservative treatment with rigid braces, specific for hyperkiphosis, associated with specific exercises. The brace was prescribed for at least 18 hours a day at the beginning of therapy.

\section{Statistics}

We compared clinical and radiographic variations between start and end of therapy. Primary outcome criteria: percentage of patients worsened $\left(>5^{\circ}\right)$, stable or improved. Secondary: thoracic kyphosis (TK), lumbar lordosis (LL), C7 and L3 distance from plumbline, sagittal index (SI), which is the distance from plumbline of C7 plus L3. We used descriptive statistics to point out average values of secondary outcome parameters and their standard deviation.

\section{Results}

We included 35 patients, mean age 14.2 \pm 1.8 (19 males).

Mean duration of treatment was $3.06 \pm 1.03$ years. In regard to our primary outcome we found 23 patients improved (66\%), 8 stable (23\%) and 4 worsened (11\%).

Highly significant improvements were found for the main spinal parameters: TK reduced from $54.8 \pm 10^{\circ}$ to $44.8 \pm 10^{\circ}(\mathrm{p}<0,001)$, LL from $55.1 \pm 8.28^{\circ}$ to $50.9 \pm 9^{\circ}$ $(\mathrm{p}=0.04)$, SI from $113.1 \pm 21 \mathrm{~mm}$ to $89 \pm 30 \mathrm{~mm}(\mathrm{p}=0.003)$ and C7 from $58.6 \pm 12 \mathrm{~mm}$ to $47.5 \pm 13 \mathrm{~mm}(\mathrm{p}=0,001)$; while L3 changed from $53 \pm 12 \mathrm{~mm}$ to $47 \pm 13 \mathrm{~mm}(\mathrm{NS})$.

\section{Conclusion}

According to our results conservative treatment with a rigid brace and specific exercise is an effective therapy of hyperkyphosis. It can significantly change both clinical and 
radiological parameters restoring more physiological values.

\section{Authors' details}

${ }^{1}$ ISICO, Italian Scientific Spine Institute, Milan, Italy. ${ }^{2}$ University of Brescia,

IRCCS Don Gnocchi, Milan, Italy.

Published: 4 December 2014

doi:10.1186/1748-7161-9-S1-039

Cite this article as: Minnella et al: Conservative treatment with brace and exercise for hyperkyphosis: a retrospective observational cohort study. Scoliosis 2014 9(Suppl 1):039.

Submit your next manuscript to BioMed Central and take full advantage of:

- Convenient online submission

- Thorough peer review

- No space constraints or color figure charges

- Immediate publication on acceptance

- Inclusion in PubMed, CAS, Scopus and Google Scholar

- Research which is freely available for redistribution

Submit your manuscript at www.biomedcentral.com/submit
C Biomed Central 